\title{
Assessment of intake of calcium and vitamin $D$ and sun exposure in the context of osteoporosis risk in a study conducted on perimenopausal women
}

\author{
Anna Kopiczko \\ Jozef Pilsudski University of Physical Education in Warsaw
}

\begin{abstract}
Introduction: The results of many epidemiological and clinical studies have shown that osteoporosis is a multifactorial disease and develops mainly in women during menopause. The aim of this study was to evaluate the diet with particular emphasis on calcium and vitamin D intake and sun exposure in premenopausal women in terms of risk of osteoporosis.

Material and methods: The study involved 300 women aged 45-55 years from Warsaw. The method used was a questionnaire assessing the frequency of consumption from the last three months. Exposure to the sun evaluated using a questionnaire prepared in cooperation with the Institute of Food and Nutrition in Warsaw. For the purpose of the project, profiles of attitudes towards prevention of osteoporosis were developed.

Results: Inadequate intake of calcium and vitamin D among the majority of women surveyed was confirmed. The highest percentage of women represented profile VIII: attitudes towards prevention of osteoporosis, characterized by insufficient exposure to sunlight and a diet deficient in both calcium and vitamin D.

Conclusions: In the diets of women surveyed significant deficiencies of calcium and vitamin D were found, which confirms previous reports on the lack of nutritional support for normal women's bone mineralization. Among the surveyed women the majority reported insufficient exposure to sunlight as a source of vitamin D additional to food. There is a need for health education of these women in the prevention of osteoporosis and especially paying attention to the proper intake of calcium and more vitamin D in their diet. At the same time, adequate exposure to the sun is vital as it is the main source of vitamin $D$ for the body coming not from the food consumed.
\end{abstract}

Key words: osteoporosis, menopause, nutrition, photo conversion of vitamin D in the skin.

\section{Introduction}

The results of many epidemiological and clinical studies have shown that osteoporosis is a multifactorial disease and develops mainly in women during menopause. The most important modifiable risk factors for osteoporosis include the ones connected with lifestyle, among which the most important are dietary factors (including in particular the customary intake of calcium and vitamin D), factors associated with physical activity and the non-food source of vitamin $D$, which is skin synthesis through exposure to sunlight $[1,2]$.

Nutrition is the primary determinant of reconfigurable chronic diseases. Change of diet eliminates errors in eating habits and has a significantly impact on improving the health and quality of life of premenopausal women. It also gives a chance to reduce the risk of osteoporosis after menopause.

In an osteoporosis preventive therapy healthy lifestyle plays a huge role. This includes proper nutrition, balanced in energy, providing the necessary nutrients in the right amounts. Among these, calcium and vitamin D are especially important.

Vitamin D is essential to maintain proper calcium and phosphorus homeostasis of the organism and to ensure the proper functioning of many tissues, organs and cells independent of the mineral market. Vitamin D deficiency increases the risk of fractures in osteoporosis and can lead to osteomalacia. An important endogenous source of vitamin $D$ is regular exposure to the sun. However, it should be noted that commonly used sun blockers can reduce the yield of synthesis of skin under the influence of UVB radiation by up to $90 \%[3,4]$.

Polish recommendations for the prevention of vitamin D deficiency developed by a group of experts carefully lay down the optimal vitamin D photo conversion in the skin. In our geographical area skin synthesis takes place from April to September, ensuring a minimum of 15 minutes sun exposure of $18 \%$ of body surface area 
(exposed arms and legs partially) from 10 am to $3 \mathrm{pm}$ without the use of protective filters. However, from October to March skin synthesis of vitamin D practically does not occur at all [5].

An essential element in determining the importance of nutrition in the path physiology and prevention of osteoporosis is insufficient calcium intake. Bone tissue is a reservoir of calcium and calcium homeostasis has a significant influence on it when the achievement of peak bone mass is reached and also later throughout life. As the body ages the process of increased release of calcium from the bones occurs. The hormonal changes of menopause also disrupt the economy of calcium $[6,7]$.

Forecasts for epidemiology of osteoporosis are worrying. Therefore, the consequences of low-energy fractures will remain a growing health problem in the world. Therefore, it is necessary to undertake studies leading to the definition of the type and number of factors responsible for the occurrence of underestimation of bone mineral density and to determine for which of them comes to the biggest and most common failures in the population of females.

The aim of this study was to evaluate the diet with particular reference to calcium and vitamin D and to sun exposure in premenopausal women in terms of osteoporosis risk.

\section{Material and methods}

The study involved 300 women aged $45-55$ years from three districts of Warsaw: Bielany, Bemowo and Wola. This sample was selected randomly from a set of women living in the area covered by the study.

Hormonal status of women was rated on the basis of a self-assessment questionnaire with the classification of the World Health Organization [8]:

- premenopause - period before menopause characterized by rhythmic menstrual cycles,

- perimenopause - period immediately preceding menopause, in which menstrual cycles are longer, become irregular or the menstrual bleeding came to an end; however, at the time of the study 12 consecutive months without bleeding have not passed from a woman's last period (amenorrhea).

The method used was the dietary interview (standardized questionnaire for the assessment of food intake of products most important for calcium and vitamin D intake) assessing the frequency of consumption of the last three months, developed in the Department of Epidemiology and Nutrition Standards of Food and Nutrition Institute in Warsaw.

The questionnaire assessing the frequency of consumption is an advanced tool that allows one to assess the frequency and quantity (g/person/day) of food intake usually in the past three months. Moreover, it allows one to assess the amount of calcium and vitamin $D$ intake in the daily food ration (mg or $\mu \mathrm{g} /$ person/day). The main part of the questionnaire contains closed questions on the usual consumption frequency of products containing calcium and vitamin D as well as their quantity. The list of products mainly included milk, dairy products divided into fermented products, dairy desserts, cheeses, white cottage cheese, blue cheese, meat and sausages, bread, cereal and cereal products, spreads (margarine, butter) and the types of water consumed. Moreover, women were also asked about the use of supplements, the dose and frequency of intake. Help in determining the type and amount of food eaten and drinks was provided by the "Photo Album of products and dishes in different sizes", incorporating 201 colour photos, prepared and published by the Institute of Food and Nutrition [9].

Statistical analysis of selected nutrient intake was performed with the computer program Diet 5.0 extended version. The interpretation of the results was made according to the guidelines for the assessment of group intake created by the Standards of Human Nutrition for the Polish population 2012 developed by the Food and Nutrition Institute in Warsaw [10]. In the intake assessment a standard average demand group, EAR (Estimated Average Requirement), was used, in the assessment of calcium and vitamin D in the diet, and taking into account the supplementation of women surveyed.

Exposure to the sun evaluated using a questionnaire prepared in cooperation with the Institute of Food and Nutrition in Warsaw.

The examination concerned the period from April to September, where due to the geographical zone skin synthesis takes place. In the winter period, due to high zenith angles of the sun, above the area of Poland a deficiency of radiating $D_{3}$ previtamin for effectiveness is observed in Poland. In relation to the daily dose recommended for the maintenance of health of $0.25 \mathrm{MED}$ [11], months in which sun exposure enables the skin synthesis of vitamin D were analysed.

The questionnaire consisted of three sections. The first section was related to sun exposure. The second part included questions about the sun exposure frequency. And finally, the third part concerned clothes worn during sun exposure and the assessment of body surface exposure to UV radiation.

For the purpose of the project 8 profiles describing attitudes towards prevention of osteoporosis were created:

- PROFILE I - high exposure to sunlight, recommended intake of calcium and vitamin D,

- PROFILE II - high exposure to sunlight, recommended intake of calcium and deficiency of vitamin D,

- PROFILE III - high exposure to sunlight, calcium deficiency, recommended intake of vitamin D, 
Tab. I. Calcium and vitamin D in the daily diet of examined women

\begin{tabular}{|c|c|c|}
\hline & Mean \pm SD & EAR for female adults* \\
\hline $\begin{array}{l}\text { Calcium } \\
\text { (mg/day) }\end{array}$ & $444.0 \pm 472.0$ & $\begin{array}{l}19-50 \text { years } 800 \mathrm{mg} / \text { day } \\
>50 \text { years } \quad 1000 \mathrm{mg} / \text { day }\end{array}$ \\
\hline $\begin{array}{l}\text { Vitamin D } \\
\text { ( } \mu \mathrm{g} / \text { day) }\end{array}$ & $2.8 \pm 2.9$ & 10 mg/day \\
\hline
\end{tabular}

*EAR (Estimated Average Requirement), Jarosz M (ed.): The standards of nutrition for the population of Polish-amendment. Food and Nutrition Institute, Warsaw 2012

- PROFILE IV - high exposure to sunlight, deficiency of calcium and vitamin D,

- PROFILE V - insufficient exposure to sunlight, recommended intake of calcium and vitamin D,

- PROFILE VI - insufficient exposure to sunlight, recommended intake of calcium, vitamin D deficiency,

- PROFILE VII - insufficient exposure to sunlight, calcium deficiency, recommended intake of vitamin D,

- PROFILE VIII - insufficient exposure to sunlight, deficiency of calcium and vitamin D.

Categories of high and insufficient exposure were developed by summing points from the data obtained from the questionnaire: the sum of the two categories frequency of exposure to the sun and the actual exposure to sunlight.

High exposure to sunlight was adopted in accordance with the guidelines and recommendations for the prevention of vitamin $\mathrm{D}$ deficiency produced by a group of experts: in the period from April to September to ensure a minimum of 15 minutes of sun exposure for at least $18 \%$ of the body surface area (exposed arms and legs in part), and, moreover, without the use of protective filters [5].

Statistical analysis of the data obtained was performed using STATISTICA. Arithmetic means and standard deviations were calculated in the data set.

The project (its goals, objectives, methods, and selection of the sample) received the consent of the Senate Ethics Committee for Scientific Research, Jozef Pilsudski University of Physical Education in Warsaw.

\section{Results}

Computer analysis of the data gathered from the interview among surveyed women showed insufficient dietary intake of calcium and vitamin D. Moreover, the average content of females' nutrients in daily food rations was located well below the normal average de-

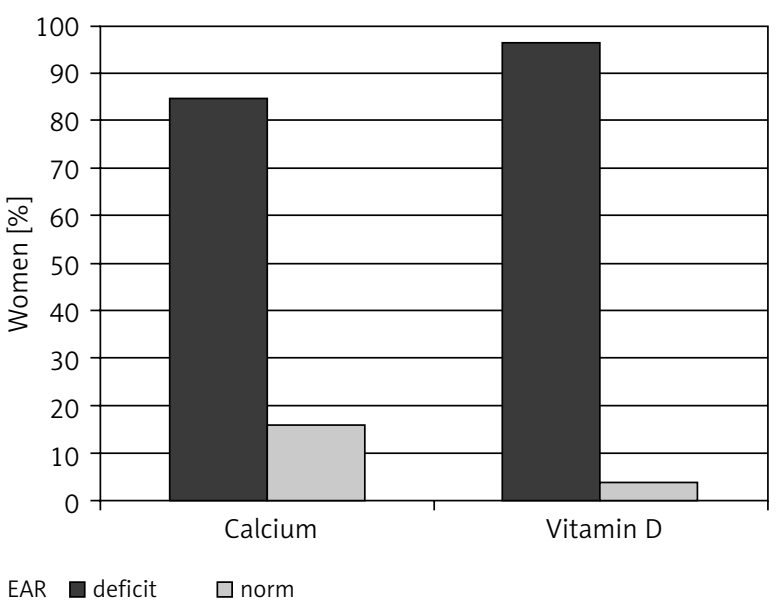

Fig. 1. Implementation of the standard EAR for calcium and vitamin $D$ in the diets of women surveyed

mand of a group EAR (Estimated Average Requirement) (Table I).

There have been a significant proportion of women who have had deficiency of both calcium and vitamin D. Intake of vitamin D recommended in the standard EAR occurred only in $3.7 \%$ of all surveyed women (Fig. 1).

The highest percentage of women surveyed reported exposure to the sun at a frequency of 1-2 times a week, or even higher than two days. Half of the respondents reported only occasional exposure to the sun (Table II).

As a result, the highest percentage of women represented profile number VIII, which describes attitudes towards prevention of osteoporosis as insufficient exposure to sunlight and dietary deficiency of both calcium and vitamin D (Fig. 2).

\section{Discussion}

Vitamin D is essential for bone health. It promotes the efficient utilization of calcium by the body. Calcium is essential for the proper functioning of the nervous system, bone growth and maintenance of normal bone density [8].

Our study reported inadequate intake of calcium and vitamin D in the diets of women surveyed. The average content of these nutrients in daily food rations was well below the normal average demand for the group recommended by EAR. This result confirms previous reports of deficiency of these nutrients in the diet of both adults and children. Significant deficiency is even

Tab. II. Weekly exposure to the sun

\begin{tabular}{|c|c|c|c|c|c|c|c|}
\hline & \multicolumn{4}{|c|}{ Frequency of exposure to the sun } & \multicolumn{3}{|c|}{ Exposure to the sun } \\
\hline & $<1$ & $1-2$ weeks & $>2$ weeks & daily & avoids & occasionally & enjoy sunshine \\
\hline Women (\%) & 9.3 & 44.0 & 43.3 & 3.4 & 17.0 & 50.0 & 33.0 \\
\hline
\end{tabular}




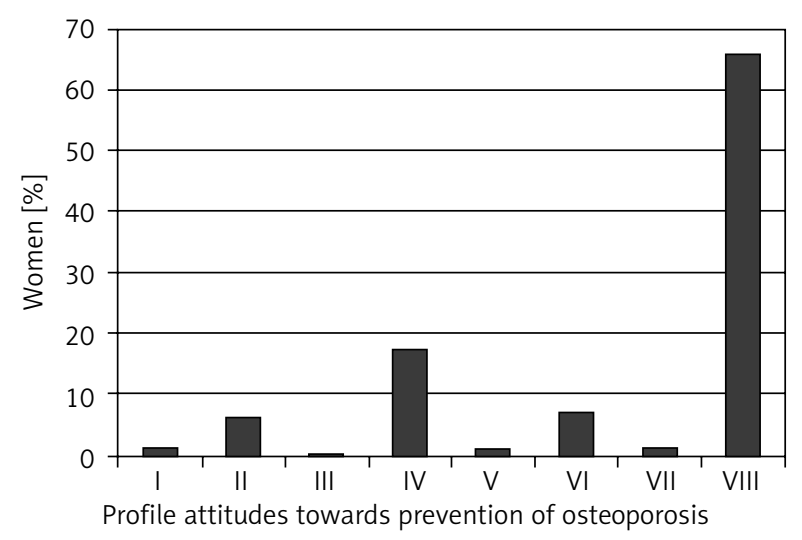

PROFILE I - high exposure to sunlight, the recommended intake of calcium vitamin D, PROFILE II - high exposure to sunlight, the recommended intake of calcium, vitamin D deficiency, PROFILE III-high exposure to sunlight, a calcium deficiency, the recommended intake of vitamin D, PROFILE IV - high exposure to sunlight, deficiency of calcium and vitamin D deficiency, PROFILE V - insufficient exposure to sunlight, the recommended intake of calcium and vitamin D, PROFILE VI - insufficient exposure to sunlight, the recommended intake of calcium, vitamin D deficiency, PROFILE VII - to insufficient exposure to sunlight, a calcium deficiency, the recommended intake of vitamin D-insufficient PROFILE VIII - exposure to sunlight, deficiency of calcium and vitamin D.

Fig. 2. Schedule profiles to the prevention of osteoporosis among women surveyed

more disturbing because of the pleiotropic effects of vitamin D (influencing more than one thing at the same time), which can protect the body against many chronic diseases including osteoporosis.

Hollis et al. found in their research that many people had insufficient levels of vitamin D, even if one takes a few thousand units per day. Thus, adult deficit of vitamin $D$ in industrialized countries is the rule rather than the exception [9].

Many authors draw attention to the fact of very common subclinical vitamin D deficiency [10]. A report of the International Osteoporosis Foundation indicates the broad global prevalence of hypovitaminosis D in almost every region of the world which was covered by the study. Although we still lack the complete data from parts of Asia and most part of Africa, vitamin D deficiency is seen as a clinical problem and significantly increases the risk of many diseases [12].

What may be worrying is the high percentage of vitamin D deficiency found in a variety of age groups in the Polish population, where the most common nutrient deficiencies in the diet (in more than $95 \%$ of the surveyed women) were found in the levels of vitamin D and calcium [11].

The human body is capable of endogenous synthesis of cholecalciferol of 7-dehydrocholesterol in the skin cells by ultraviolet radiation. Therefore, the efficiency of this process is dependent on skin pigmentation, age, time of exposure to sun and the latitude in which we live. Deficiency of vitamin D in the body can be caused by too low endogenous synthesis or by insufficient supply in the diet $[13,14]$.
The vast majority of surveyed women from Warsaw presented the least favourable profile of attitudes towards prevention of osteoporosis. Insufficient exposure to sunlight and at the same time deficiency of calcium and vitamin $D$ from their diet show a lack of healthrelated behaviours regarding bone protection against osteoporosis.

This is a negative conclusion for the group study, because the shortage of food calcium must be rebalanced at the expense of bone tissue. This increases the pace of decline in bone density. It is estimated that approximately $80-100 \%$ of the daily requirement for vitamin $D_{3}$ is derived from biosynthesis in the skin, and only to a small extent is supported by dietary sources. Among the examined groups of women it was found that the acquisition of vitamin D from diet as well as from outside sources is not sufficient. As a result this leads to higher risk of osteoporosis in elderly life.

Insufficient exposure to sunlight may be associated with fear of skin diseases including melanoma. It has been proven that excessive exposure to sunlight increases the risk of skin cancer, but there is no evidence that reasonable exposure to the sun increases this risk. Therefore, reasonable and recommended skin exposure to the sun should be perceived as the best source of vitamin D. Exposure to the sun as a result of which we observe the minimum erythema is equivalent to about 20,000 IU vitamin D from food and supplements. Thus, the exposure of arms and legs to ensure a minimum dose can be compared to the consumption of approximately 3000 IU of vitamin D [15].

Nutritional support (adequate intake of calcium and vitamin D in diet, use of products enriched with calcium and vitamin D, right supplementation) and appropriate exposure to the sun as the main external source of vitamin $D$ are important aspects of physiological slowing the loss of BMD in premenopausal women. Moreover, they can be considered as the main means of prevention of osteoporosis in postmenopausal women.

\section{Conclusions}

1. Proper diet according to the recommendations determines an adequate supply of calcium and vitamin D which is important to maintaining the health and well-being of the skeletal system.

2. Equally important is adequate exposure to the sun as the main non-nutrition source of vitamin D both to allow achieving peak bone mass, and as the main factor in the prevention of osteoporosis.

3. An important element of the prevention of diseases of the skeletal system is provided by nutritional education and modification of women's behaviour toward a healthy lifestyle. 


\section{Acknowledgement}

I would like to give my special thanks to Professor Jadwiga Charzewska for her kindness, support and extra effort in directing me in my work.

The project is financed by the Jozef Pilsudski University of Physical Education in Warsaw as part of the activities of young scientists (DM-14).

\section{Disclosure}

Author reports no conflicts of interest.

\section{References}

1. Chwojnowska Z, Charzewska J. Osteoporoza - aktualne wyzwanie. Żyw Człow Metab 2008; 35: 151-184.

2. Bronkowska M, Sadowska D. Ocena sposobu żywienia kobiet w okresie okołomenopauzalnym w aspekcie zagrożenia chorobami cywilizacyjnymi - spożycie wybranych składników pokarmowych. Żywność Nauka Technologia Jakość 2007; 6: 359-368.

3. Marcinowska-Suchowierska E, Walicka M, Tałataj M, et al. Vitamin D supplementation in adults - guidelines. Pol J Endocrinol 2010; 61: 723-729.

4. Holick MF. Vitamin D deficiency. NEJM 2007; 357: 266.

5. Dobrzańska A, Charzewska J, Chlebna-Sokół D, et al. Polskie zalecenia dotyczące profilaktyki niedoborów witaminy D - 2009. Pol Merk Lek 2010; 28: 130-133.

6. Heaney RP. Calcium in the prevention and treatment of osteoporosis. J Int Med 1992; 231: 169-180.
7. Marcinkowska M, Ignaszak-Szczepaniak M, Wawrzyniak A, et al. A discussion of the intervention thresholds in osteoporosis treatment in Poland. Endokrynol Pol 2011; 62: 30-36.

8. World Health Organization. Research on the menopause: report of a WHO Scientific Group. WHO Technical Report Series no. 670. Geneva, 1981.

9. Szponar L, Wolnicka K, Rychlik E. Album fotografii produktów i potraw. Warszawa 2000

10. Jarosz $M$ (red.). Normy żywienia dla populacji polskiej - nowelizacja. Instytut Żywności i Żywienia, Warszawa 2012.

11. Holick MF. High prevalence of vitamin D inadequacy and implications for health. Mayo Clin Proc 2006; 81: 353-373.

12. Mithal i wsp. 2009

13. Kuryłowicz A, Bednarczuk T, Nauman J. Wpływ niedoboru witaminy D na rozwój nowotworów i chorób autoimmunologicznych. Pol J Endocrinol 2007; 58: 140-152.

14. Hollis BW, Wagner CL. Vitamin D requirements during lactation: highdose maternal supplementation as a therapy to prevent hypovitaminosis D for both the mother and the nursing infant. Am J Clin Nutr 2004; 80 (suppl): $17522 \mathrm{~s}-17528 \mathrm{~s}$.

15. Hossein-nezhad A, Holick MF. Vitamin D for health: a global perspective. Mayo Clin Proc 2013; 88: 720-755.

16. Adams JS, Liu PT, Chun R, et al. Vitamin D in defense of the human immune response. Ann NY Acad Sci 2007; 1117: 94-105.

17. Andersen R, Molgaard C, Skovgaard LT, et al. Teenage girls and elderly women living in northern Europe have low winter vitamin D status. Eur J Clin Nutr 2005; 59: 533-541.

18. Athyros VG, Ganotakis ES, Elisaf M, et al. The prevalence of the metabolic syndrome Rusing the National Cholesterol Educational Program and International Diabetes Federation definitions. Curr Med Res Opinion 2005; 21: 1157-1159.

19. Ball GFM. Vitamins in Foods. Analysis, Bioavailability, and Stability. CRC Press, Taylor \& Francis, Boca Raton 2006 